\title{
Changes in Physical Strength and Performance of Rugby Union Male Student-Athletes over 70- Weeks and after the First 31-Weeks of Training
}

\author{
By Neetu Rishiraj \\ Brian Niven ${ }^{\dagger}$
}

\begin{abstract}
Physical and physiological demands of the 15-a-side rugby union (RU) game have increased since the sport attained professional status. However, little data are available on these variables concentrating on developing $R U$ players (studentathletes). The purpose of this paper was to investigate the potential enhancement of two physical strength and nine performance variables of male New Zealand RU Academy student-athletes over 70-weeks, a 39-week subset of this duration, and compare with available data. Nine Otago Rugby Football Union student-athletes were part of the second-year Otago Rugby Football Union (ORFU) Academy Program. Over the initial 35-weeks and weeks 53 to 70, each week the student-athletes engaged in 25hours of actively supervised Academy training program and participated in 15-hours of rugby practice and game play. During weeks 36 to 52, the student-athletes trained on their own following their provided individualized training programs. Assessments sessions were scheduled over 52-weeks. Over 70-weeks, analysis of the mean data revealed increases in body weight and skinfold measurements with concurrent significant performance improvements in lower-body power (13.9\%; ES = Large; $p=0.001)$, upper body strength - bench press $(22.1 \%$; ES = Large; $p=0.005)$, - bench pull $(9.2 \%$; $E S=$ Large $; p=0.018)$, and anaerobic capacity - PDT-Effort $(6.8 \% ; E S=$ Large; $p=$ 0.026). Mean data over 39-weeks (weeks 31 to 70) demonstrated a $1.6 \%$ body weight increase with concurrent $2.7 \%$ decrease in skinfolds and significant performance enhancement in upper body strength - bench pull (9.2\%; ES = Large; $p=0.013)$ and PDT-Effort (7.4\%; ES = Large; $p=0.050)$. Significant performance enhancement for lower-body power, upper-body strength, and PDT-Effort over 70-weeks is possible even with increases in body weight and skinfold measurements. In conclusion, over weeks 31 to 70, body weight continued to increase, skin-fold measurement decreased and performance improvement was noted in all variables, with significant development in upper-body strength and PDT-Effort. Also, the above results were recorded even after a non-active monitoring training period.
\end{abstract}

Keywords:Male student-athletes, physical and performance variables, rugby union.

\section{Introduction}

As a result of achieving professional status the intensity of the Rugby Union (RU) game play has increased, specifically, greater number of collisions, passes, rucks, tackles, tries, and ball-in-play time/work-rest ratio that has led to an

\footnotetext{
*Director, ACTIN Health \& Rehabilitation Inc., Vancouver, BC, Canada.

${ }^{\dagger}$ Senior Lecturer, Department of Mathematics \& Statistics, University of Otago, Dunedin, New Zealand.
} 
increase in the physical and physiological demands for players (Cahill et al. 2013). To overcome these physical and physiological RU game demands, prevent injury, allow for the possibility of advancing to the respective senior national program and/or the professional level of play, as well as to enhance career longevity, RU players must start at a young age to enhance their physical stature and energy systems. Although, compared to other professional European and North American sports, limited published data is now available on the physical and/or performance characteristics of professional RU players, data on RU developing/Academy student - athletes remain sparse; with long term data on developing RU players being negligible. The limited available data has suggested that approximately $81 \%$ of strength and $71 \%$ of power increase occurs during the first two years (training age 1.5 years) in developing athletes (Argus et al. 2012). Since available literature also suggests only up to $30 \%$ of the players representing a junior national RU team maybe adequately prepared to advance to a senior national program (Parker, 2013) greater data are required to enhance player development. To assist in physical strength and performance enhancement of developing/Academy student-athletes the primary purpose of this research was to investigate respective changes in male New Zealand Academy StudentAthletes (NZASA) over 70-weeks, over the latter 39-weeks of training, and, where possible, compare with available data from international Academy RU athletes. The secondary purpose was to ascertain if non-active training monitoring/ supervision of student-athletes led to changes in physical and/or performance variables.

\section{Methods}

\section{Participants - Physical Data}

The age range of the nine male NZASA was 19 to 21 years and the pooled (4 forwards and 5 backs) mean body weight was $91.9 \mathrm{~kg}$ with a standard deviation $\pm 15.5 \mathrm{~kg}$ at week-31 and $93.4 \pm 10.9 \mathrm{~kg}$ over 70 -weeks. The pooled mean of the 7-skin fold sites(Hawes and Martin 2001) was $106.1 \pm 34.1 \mathrm{~cm}$ (week-31) and $103.2 \mathrm{~cm} \pm 25.9 \mathrm{~cm}$ (weeks 1 to 70 ). Detailed body weight and skin fold data are presented in Table 1 .

\section{Experimental Set-up}

Twenty male student-athletes from across New Zealand were recruited by the NZ Otago Rugby Football Union (ORFU) for their Academy program. After year 1, due to various reasons (Figure 1) nine student-athletes remained in the ORFU Academy program. Ethical approval was obtained from the institutional Ethics Committee and an informed consent was received from each ORFU student-athlete at the start of year 1 of the program. To address any potential medical concern(s), injury history and medical information was reviewed with the respective player and the ORFU Academy Manager. 
Table 1. NZ Academy Male Student-Athlete (N=9) Physical and Performance Changes over 70-Weeks and 39- (31-70) Weeks, with Comparable Data

\begin{tabular}{|c|c|c|c|c|c|c|c|c|c|c|}
\hline & \multirow{2}{*}{$\begin{array}{c}\text { Mean } \pm \text { SD } \\
(\% \text { Change }) \dagger\end{array}$} & \multicolumn{2}{|c|}{ Range } & \multicolumn{2}{|c|}{$95 \%$ CI } & \multirow{2}{*}{$\begin{array}{l}\text { CohenEffect } \\
\text { Size \& } \\
\text { (Descriptor) }\end{array}$} & \multirow{2}{*}{$\begin{array}{l}\text { English } \\
\text { Academy } \\
\text { U21 RU§ }\end{array}$} & \multirow{2}{*}{$\begin{array}{c}\text { South } \\
\text { African } \\
\text { U20 RUTI }\end{array}$} & \multirow{2}{*}{$\begin{array}{c}\text { NZ } \\
\text { Academy } \\
\text { U21 RU** }\end{array}$} & \multirow{2}{*}{$\begin{array}{c}\text { National } \\
\text { Team } \\
\text { Academy } \\
\text { U20 RUt† } \\
\end{array}$} \\
\hline & & Min & Max & Lower & Upper & & & & & \\
\hline \multicolumn{11}{|l|}{ Body Weight (kg) } \\
\hline $\begin{array}{c}\text { Week (Wk) } 1 \\
\text { March }\end{array}$ & $90.5 \pm 12.0$ & 73.1 & 112.3 & 81.3 & 99.7 & \multirow{3}{*}{$\begin{array}{c}0.25 \text { (Small) } \\
0.11 \text { (Trivial) }\end{array}$} & $98.3 \pm 10.4$ & $\begin{array}{c}1998 \\
86.5 \pm 9.5\end{array}$ & $95.6 \pm 11.0$ & $92.2 \pm 8.8$ \\
\hline $\begin{array}{l}\text { Week } 31 \\
\text { October }\end{array}$ & $91.9 \pm 15.5$ & 74.6 & 115.7 & 80.0 & 103.9 & & \multirow{2}{*}{\multicolumn{2}{|c|}{$\begin{array}{c}2009 \\
98.0 \pm 7.5 \\
(13.3)\end{array}$}} & & \multirow{2}{*}{$\begin{array}{c}93.6 \pm 8.3 \\
\text { Year 1: (1.5) } \\
\text { Year 2: }(4.8)\end{array}$} \\
\hline $\begin{array}{l}\text { Week } 70 \\
\text { July }\end{array}$ & $\begin{array}{c}93.4 \pm 10.9 \\
\text { Wks } 1-70(3.2) \\
\text { Wks } 31-70(1.6)\end{array}$ & 80.2 & 113.0 & 85.0 & 101.8 & & & & & \\
\hline \multicolumn{11}{|l|}{ Skin Folds (mm)* } \\
\hline $\begin{array}{l}\text { Week } 1 \\
\text { March }\end{array}$ & $98.1 \pm 31.6$ & 53.0 & 161.0 & 74.1 & 122.7 & \multirow{3}{*}{$\begin{array}{l}0.18 \text { (Trivial) } \\
0.10 \text { (Trivial) }\end{array}$} & $\begin{array}{c}105.3 \pm \\
35.4\end{array}$ & & & \\
\hline $\begin{array}{l}\text { Week } 31 \\
\text { October }\end{array}$ & $106.1 \pm 34.1$ & 52.5 & 169.0 & 79.8 & 132.4 & & & & & \\
\hline $\begin{array}{l}\text { Week } 70 \\
\text { July }\end{array}$ & $\begin{array}{c}103.2 \pm 25.9 \\
W k s 1-70(4.9) \\
W k s 31-70(- \\
2.7)\end{array}$ & 62.0 & 159.0 & 83.3 & 123.1 & & & & & \\
\hline Vertical Jump (cm) & \multicolumn{6}{|c|}{ Significant: Weeks 1 to $70 ; p=0.001$} & & & & \\
\hline $\begin{array}{l}\text { Week } 1 \\
\text { March }\end{array}$ & $55.1 \pm 4.7$ & 48.0 & 62.0 & 51.5 & 58.7 & \multirow{3}{*}{$\begin{array}{c}1.46 \text { (Large) } \\
0.14 \text { (Trivial) }\end{array}$} & \multirow[t]{3}{*}{$47.1 \pm 3.6$} & & & \\
\hline $\begin{array}{l}\text { Week } 31 \\
\text { October }\end{array}$ & $61.9 \pm 7.1$ & 52.0 & 84.0 & 58.1 & 64.7 & & & & & \\
\hline $\begin{array}{l}\text { Week } 70 \\
\text { July }\end{array}$ & $\begin{array}{c}62.8 \pm 5.8 \\
W k s 1-70(13.9) \\
W k s 31-70(1.4)\end{array}$ & 54.0 & 69.0 & 58.3 & 67.3 & & & & & \\
\hline
\end{tabular}




\begin{tabular}{|c|c|c|c|c|c|c|c|c|c|}
\hline 5m Sprint (s) & \multicolumn{6}{|c|}{ Not Sig $\rightarrow$ Wks 1-70 \& Wks 31 to 70} & \multirow{2}{*}{\multicolumn{3}{|c|}{$\begin{array}{c}1.07 \pm \\
0.07\end{array}$}} \\
\hline $\begin{array}{l}\text { Week } 1 \\
\text { March }\end{array}$ & $1.04 \pm 0.04$ & 0.99 & 1.11 & 1.00 & 1.06 & \multirow{3}{*}{$\begin{array}{c}1.00 \text { (Large) } \\
0.59 \text { (Medium) }\end{array}$} & & & \\
\hline $\begin{array}{l}\text { Week } 31 \\
\text { October }\end{array}$ & $1.03 \pm 0.06$ & 0.93 & 1.16 & 0.97 & 1.07 & & & & \\
\hline $\begin{array}{l}\text { Week } 70 \\
\text { July }\end{array}$ & $\begin{array}{c}1.00 \pm 0.04 \\
W k s 1-70(-3.8) \\
W k s 31-70(-3.1)\end{array}$ & 0.94 & 1.06 & 0.96 & 1.02 & & & & \\
\hline \multicolumn{10}{|l|}{ 10m Sprint (s) } \\
\hline $\begin{array}{l}\text { Week } 1 \\
\text { March }\end{array}$ & $1.75 \pm 0.70$ & 1.67 & 1.85 & 1.69 & 1.80 & \multirow{3}{*}{$\begin{array}{l}0.02 \text { (Trivial) } \\
0.00 \text { (Trivial) }\end{array}$} & $\begin{array}{c}1.79 \pm \\
0.10\end{array}$ & $\begin{array}{c}1998 \\
1.86 \pm 0.10\end{array}$ & \\
\hline $\begin{array}{l}\text { Week } 31 \\
\text { October }\end{array}$ & $1.74 \pm 0.08$ & 1.61 & 1.91 & 1.68 & 1.81 & & \multirow{2}{*}{\multicolumn{3}{|c|}{$\begin{array}{c}2010 \\
1.73 \pm 0.10 \\
(7.0)\end{array}$}} \\
\hline $\begin{array}{l}\text { Week } 70 \\
\text { July }\end{array}$ & $\begin{array}{c}1.74 \pm 0.50 \\
\text { Wks } 1-70(-0.4) \\
\text { Wks } 31-70(-0.3)\end{array}$ & 1.70 & 1.86 & 1.70 & 1.78 & & & & \\
\hline \multicolumn{10}{|l|}{ 40m Sprint (s) } \\
\hline $\begin{array}{l}\text { Week } 1 \\
\text { March }\end{array}$ & $5.35 \pm 0.25$ & 5.06 & 5.75 & 5.15 & 5.54 & \multirow{3}{*}{$\begin{array}{l}0.27 \text { (Small) } \\
0.30 \text { (Small) }\end{array}$} & $\begin{array}{c}5.43 \pm \\
0.21\end{array}$ & $\begin{array}{c}1998 \\
5.44 \pm 0.20\end{array}$ & \\
\hline $\begin{array}{l}\text { Week } 31 \\
\text { October }\end{array}$ & $5.35 \pm 0.21$ & 4.98 & 5.64 & 5.19 & 5.51 & & \multirow{2}{*}{\multicolumn{3}{|c|}{$\begin{array}{c}2010 \\
5.23 \pm 0.30 \\
(3.9)\end{array}$}} \\
\hline $\begin{array}{l}\text { Week } 70 \\
\text { July }\end{array}$ & $\begin{array}{c}5.29 \pm 0.19 \\
W k s 1-70(-1.2) \\
W k s 31-70(-1.2)\end{array}$ & 5.06 & 5.58 & 5.13 & 5.43 & & & & \\
\hline Bench Press (kg; 1RM) & \multicolumn{6}{|c|}{ Significant: Weeks 1 to $70 ; p=0.005$} & & & \\
\hline $\begin{array}{l}\text { Week 1 } \\
\text { March }\end{array}$ & $100.2 \pm 14.5$ & 80.0 & 125.0 & 89.0 & 111.4 & \multirow{3}{*}{$\begin{array}{c}1.55 \text { (Large) } \\
0.17 \text { (Trivial) }\end{array}$} & $\begin{array}{c}108.2 \pm \\
14.1\end{array}$ & $\begin{array}{c}1998 \\
89.0 \pm 18.0\end{array}$ & $115 \pm 16$ \\
\hline $\begin{array}{l}\text { Week } 31 \\
\text { October }\end{array}$ & $120.0 \pm 13.8$ & 93.0 & 134.0 & 109.4 & 130.5 & & \multirow{2}{*}{\multicolumn{3}{|c|}{$\begin{array}{c}2010 \\
135.0 \pm 22.0 \\
(51.7)\end{array}$}} \\
\hline $\begin{array}{l}\text { Week } 70 \\
\text { July }\end{array}$ & $\begin{array}{c}122.4 \pm 14.1 \\
\text { Wks } 1-70(22.1) \\
\text { Wks } 31-70(2.0)\end{array}$ & 93.0 & 139.0 & 111.6 & 133.2 & & & & \\
\hline
\end{tabular}




\begin{tabular}{|c|c|c|c|c|c|c|c|}
\hline Bench Pull(kg; 1RM) & \multicolumn{6}{|c|}{ Significant: Weeks 1 to $70 ; p=0.018 \&$ Weeks 31 to $70 ; p=0.013$} & \\
\hline $\begin{array}{l}\text { Week } 1 \\
\text { March }\end{array}$ & $88.0 \pm 6.2$ & 74.0 & 93.0 & 83.2 & 92.8 & \multirow{3}{*}{$\begin{array}{l}1.35 \text { (Large) } \\
0.84 \text { (Large) }\end{array}$} & $\begin{array}{c}96.8 \pm \\
8.2\end{array}$ \\
\hline $\begin{array}{l}\text { Week } 31 \\
\text { October }\end{array}$ & & 85.0 & 98.0 & 88.3 & 94.8 & & \\
\hline $\begin{array}{l}\text { Week } 70 \\
\text { July }\end{array}$ & $\begin{array}{c}96.1 \pm 5.8 \\
\text { Wks } 1-70(9.2) \\
\text { Wks 31-70 (5.0) }\end{array}$ & 86.2 & 103.0 & 91.7 & 100.6 & & \\
\hline \multicolumn{8}{|l|}{ PDT-Mean (sec) } \\
\hline $\begin{array}{l}\text { Week } 1 \\
\text { March }\end{array}$ & $5.96 \pm 0.31$ & 5.57 & 6.56 & 5.72 & 6.19 & \multirow{3}{*}{$\begin{array}{l}0.24 \text { (Small) } \\
0.24 \text { (Small) }\end{array}$} & \\
\hline $\begin{array}{l}\text { Week } 31 \\
\text { October }\end{array}$ & $5.96 \pm 0.33$ & 5.59 & 6.56 & 5.70 & 6.22 & & \\
\hline $\begin{array}{l}\text { Week } 70 \\
\text { July }\end{array}$ & $\begin{array}{c}5.89 \pm 0.28 \\
\text { Wks 1-70(-1.1) } \\
\text { Wks 31-70 (-1.1) }\end{array}$ & 5.65 & 6.45 & 5.68 & 6.11 & & \\
\hline \multicolumn{8}{|l|}{ PDT-Fatigue (\%) } \\
\hline $\begin{array}{l}\text { Week } 1 \\
\text { March }\end{array}$ & $14.2 \pm 6.2$ & 7.60 & 27.0 & 9.44 & 18.9 & \multirow{3}{*}{$\begin{array}{l}0.19 \text { (Trivial) } \\
0.10 \text { (Trivial) }\end{array}$} & \\
\hline $\begin{array}{l}\text { Week } 31 \\
\text { October }\end{array}$ & $13.7 \pm 6.5$ & 6.85 & 23.9 & 8.73 & 18.6 & & \\
\hline $\begin{array}{l}\text { Week } 70 \\
\text { July }\end{array}$ & $\begin{array}{c}13.1 \pm 5.2 \\
\text { Wks } 1-70(-7.2) \\
\text { Wks } 31-70(-3.7)\end{array}$ & 7.71 & 24.4 & 9.15 & 17.2 & & \\
\hline PDT-Effort (\%) & \multicolumn{6}{|c|}{ Significant: Weeks 1 to $70 ; p=0.026 \&$ Wks 31 to $70 ; p=0.050$} & \\
\hline $\begin{array}{l}\text { Week } 1 \\
\text { March }\end{array}$ & $96.6 \pm 1.1$ & 94.2 & 98.0 & 95.7 & 97.5 & \multirow{3}{*}{$\begin{array}{l}1.30 \text { (Large) } \\
1.33 \text { (Large) }\end{array}$} & \\
\hline $\begin{array}{l}\text { Week } 31 \\
\text { October }\end{array}$ & $97.2 \pm 2.9$ & 90.5 & 99.5 & 94.9 & 99.4 & & \\
\hline $\begin{array}{l}\text { Week } 70 \\
\text { July }\end{array}$ & $\begin{array}{c}90.0 \pm 7.1 \downarrow \\
\text { Wks 1-70 (-6.8) } \\
\text { Wks 31-70 (-7.4) }\end{array}$ & 79.3 & 98.7 & 84.6 & 95.5 & & \\
\hline
\end{tabular}


Body Weight was measured using a calibrated electronic scale (A \& D Engineering Inc.).

1RM: One repetition maximum.

RU: Rugby Union.

*Skin Fold: Sum of 7 skin folds; An experienced nutritionist performed all skinfold tests following previous published methods. Measurements were taken using calibrated Harpenden ${ }^{\circledR}$ Skinfold Callipers at the following site: abdomen, chest, midaxillary, quadriceps, subscapular, suprailiac, and triceps (Bell 1973).

$\dagger$ Percent (\%) change: Week 1 (season-start) to week 70 (season-start following year) and week 31 (in-season) to week 70; latter over 39 weeks.

$\$($ Cohen1988)

$\S$ Data collected from fifteen U21 male English Academy RU players; playing position not specified. Authors used sum of eight site skinfolds (biceps, triceps, subscapular, suprailliac, abdominal, supraspinale, front thigh and medial calf). Data collected at 'season-start' (June) after a 6-week off-season training period (DarrallJones et al. 2015).

II|Data collection over 11- to 13-years from 453 (forwards = 256 and backs = 197) players representing a Junior (U20) South African National Team. Mean (combined forwards and backs) data of the respective duration presented. Mean age of the players was $18.1 \pm 0.7$ years. Data collected at the start, December / January, of respective season(Lombard et al. 2015).

**Total of 32 subjects (mean age $19.6 \pm 1.8$ ) competing in either age group provincial level or B-level provincial competition. Subjects had completed $0.7 \pm 0.5$ months of high school and $1.5 \pm 1.1$ years of Academy supervised training(Quarrie et al. 1995).

††Thirty-one U20 (mean age $19.2 \pm 0.9$ ) national team players (17 forwards and 14 backs) also from a national team ranked as $11^{\text {th }}$ to $15^{\text {th }}$ in world rankings by the International Rugby Board. All of study participants were training on a full-time basis at a national team training academy. Each of the participants was typically involved in approximately 8-12 weeks per year of national team duty, 24 weeks of club rugby, 12-16 weeks of pre-season training, and 4 weeks of rest. Testing sessions scheduled after 1-year and 2-years of training(Barr et al. 2014). 
Figure 1. Reasons for Subject Attrition after Week 52

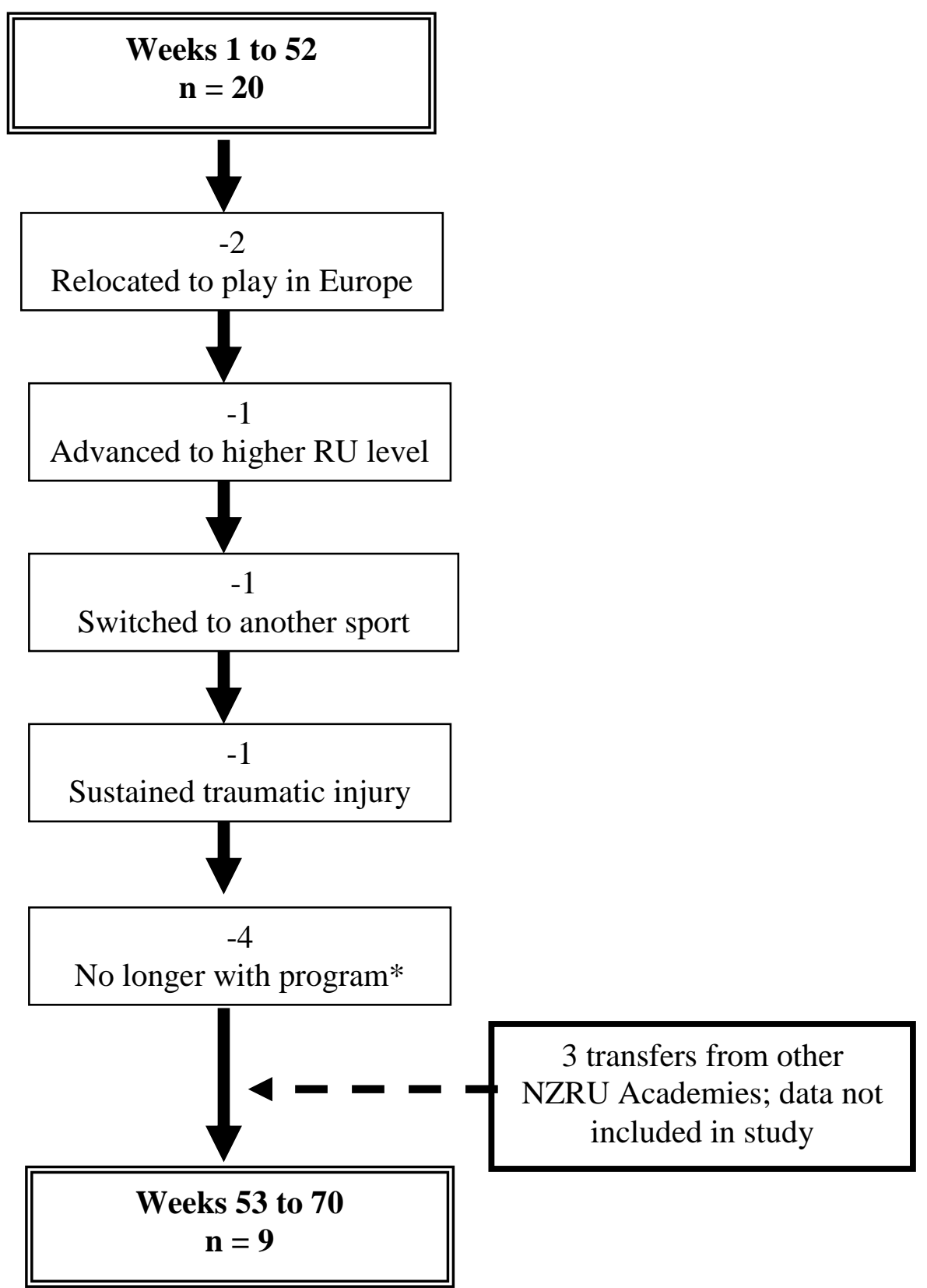

*Due to education, personal, and / or professional concern(s).

NZRU: New Zealand Rugby Union

\section{Experimental Procedure}

All NZASA were actively participating on an ORFU premier division team. Under active supervision the NZASA trained up to 25-hours per week with additional 15-hours scheduled for team practices and game play (Table 2). Three testing sessions were scheduled over 52-weeks, week 1 - 'season-start', week 18 - 'in-season', and week 31 - 'competitive-season'. During weeks 36 to 52 ('off-season'), due to the student-athletes returning home over summer break, 
respective players were provided individualised training programs, were not actively supervised, but training was monitored via a secure online (non-video) media source. After the off-season, the following year, testing sessions started with week 53 -'season-start' and then followed the annual schedule. Prior to the start of the program, the definition for 'competitive-season' (weeks 1 - 31) was established and pre-playoff (week 31) testing session was scheduled to ensure physical and performance data were collected from the maximum number of student-athletes.

Table 2. New Zealand Academy Male Student Athlete Weekly Game, Practice, and Training Schedule over 70-Weeks and 39- (31-70) Weeks

\begin{tabular}{|lllllll||}
\hline Sunday & Monday & Tuesday & Wednesday & Thursday & Friday & Saturday \\
\hline AM: & AM: & AM: & AM: & AM: & AM: & \\
Recovery & Weight & Core \& & Weight & Core \& & Activation & \\
Session* & Training & $\begin{array}{l}\text { Flexibility } \\
\text { Training }\end{array}$ & Training & $\begin{array}{l}\text { Flexibility } \\
\text { Training }\end{array}$ & Session & \\
& & & & & \\
& & & $\begin{array}{l}\text { Noon: } \\
\text { Individual } \\
\text { specific } \\
\text { training }\end{array}$ & & & \\
& & & & & & GAME \\
& & & & & & DAY \\
& & & PM: & PM: & PM: & \\
PM: & PM: & PM: & Team & REST & \\
REST & Aerobic/ & Team & Speed \& & & \\
& Anaerobic & Practice & Agility & Practice & & \\
& Training & & Training & & & \\
\hline
\end{tabular}

*Recovery session consisted of aerobic, stretching, and massage (latter, budget dependant) followed by a team brunch.

$\uparrow$ Activation session involved aerobic and flexibility activities for 30-45 minutes duration.

\section{Performance Tests Completed}

All subjects performed five standardized performance tests, with data being collected on nine performance variables. The respective performance tests and testing procedures as well as the documented test reliability for each test are as follows:

1. Lower-body Power - Vertical Jump (VJ): The subjects first stood erect, their feet flat on the floor and hips perpendicular to the Vertec (Sports Imports, $\mathrm{OH}, \mathrm{USA}$ ) vertical jump testing apparatus and with their dominant hand reach high as possible to determined their static vertical reach. Without moving their feet prior to the jump subjects flexed their knees, jumped and touched, again with the dominant hand, the highest point on the Vertec. The distance between the static vertical reach point and the peak jump height was used to determine the maximal vertical jump distance in centimetres. Subjects performed three trials with a one-minute rest between trials. The coefficient 
of variance $(\mathrm{CV}) /$ reliability has been documented to be 5.3\% (Moir et al. 2004; Hendrick and Anderson 1996).

2. Acceleration and Speed $-5 \mathrm{~m}, 10 \mathrm{~m}$, and $40 \mathrm{~m}$ : The timed run commenced from a standing start and subjects sprinted through the $5 \mathrm{~m}, 10 \mathrm{~m}$, and $40 \mathrm{~m}$ timing gates. Sprint elapsed time (seconds) was recorded using electronic gates (Brower Training System, Draper, UT, USA]) set at a height of $75 \mathrm{~cm}$. Subjects performed three trials with a one-minute rest between trials. The CV under similar protocols has been shown to be 1.9-2.0\% (Moir et al. 2004; Baker and Newton 2008).

3. Upper-body Strength - Bench Press: Using Olympic equipment subjects performed the test with their feet flat on the floor and the buttocks/lower back remained in contact with the bench throughout the lift. A shoulder width grip was used during the lift. The bar was lowered to the chest (elbows flexed to $90^{\circ}$ and not bouncing off the chest) and returned to the start position; elbows fully extended but not locked. A series of maximal lift attempts were performed until a final 1RM was completed; data was recorded as $1 \mathrm{RM}$ in kilograms. The CV has been established to be $1.5 \%$ (Coutts et al. 2007; McCurdy et al. 2008).

4. Upper-body Strength - Bench Pull: Again, using Olympic equipment, with the athlete lying prone on a bench, chin in contact with the bench, the athlete pulled the barbell upwards until it reached the underside of the bench. A series of maximal lift attempts were performed until a final 1RM was successful; data was recorded as $1 \mathrm{RM}$ in kilograms. A similar test reported a CV of $2.3 \%$ (Seo et al. 2012; Lawton et al. 2011).

5. Anaerobic Endurance - Phosphate Decrement Test (PDT): Subjects performed 10 x 40 m sprints, every 30 seconds. Sprint elapsed times were recorded in seconds using electronic gates (Brower Training System) after each $40 \mathrm{~m}$ sprint. A comparable repeat sprint evaluation reported a CV of $1.9 \%$ (Glaister et al. 2007; Tønnessen et al. 2011). Subjects performed the PDT once (10 x 40 sprints). Data was expressed as:

- (5A) Mean PDT being the average of all $10 \times 40 \mathrm{~m}$ sprint repeats.

- (5B) Percent Fatigue provided data on the fatigue rate or performance 'drop-off' over the total $400 \mathrm{~m}$ (10 x $40 \mathrm{~m}$ sprint) distance.

- (5C) Percent Effort was obtained by comparing the Fastest PDT Sprint Repeat time with the Fastest $40 \mathrm{~m}$ Acceleration-Speed result during the $10 \times 40$ m sprint repeats.

All anaerobic capacity and sprint testing was completed on an indoor Balsam ProBounce sand filled synthetic carpet surface.

An aerobic capacity test ( $1500 \mathrm{~m}$ run on an outdoor rubberized $400 \mathrm{~m}$ track) was also scheduled, however, poor weather conditions prevented data collection. 


\section{Statistical Analysis}

Analysis of the changes in body weight, skinfold measurements, and performance levels of the NZASA over a 70-week period and 39-weeks (weeks 31 to 70 ) were completed using descriptive statistics (mean, SD, minimum and maximum range, and confidence intervals). Independent t-tests, weeks $1-70$ and weeks $31-70$, were performed to detect possible physical and performance changes over the respective durations, with significance being determined at the $\mathrm{p}<0.05$ level. Analysis over weeks 31 to 70 (39-weeks) was performed to determine if performance changes occurred after the initial introduction, over weeks 1 to 31, to actively supervised training(Smart et al. 2013; Argus et al. 2012), Furthermore, the magnitude of the differences between the means was described using Cohen's effect sizes (ES) with the corresponding descriptors, trivial $=0-0.19$, small $=0.20-0.49$, medium $=0.50-0.79$, and large $=>0.80$ (Cohen 1988). Data analysis was performed using SPSS for Windows version 13.0, SPSS Inc, Chicago, Ill, USA.

\section{Results}

Mean data from the nine student-athletes over 70-weeks demonstrated a small ES increase (3.2\%) in body weight along with a trivial ES (4.9\%) increase in skinfolds. Over weeks 31 to 70 (39-weeks), only trivial ES was found in both physical variables; body weight increased by $1.6 \%$ with $2.7 \%$ concurrent decrease in skinfolds.

Over 70-weeks, enhancement of performance variables, ES ranging from trivial to large with $0.4 \%$ to $22.1 \%$, was noted, with significance being achieved in lower-body power $(13.9 \%$; $\mathrm{ES}=$ Large; $\mathrm{p}=0.001)$, upper body strength - bench press $(22.1 \%$; ES $=$ Large; $\mathrm{p}=0.001)$ and -bench pull $(9.2 \%$; $\mathrm{ES}=$ Large; $\mathrm{p}=0.018)$, as well as PDT-Effort (6.8\%; $\mathrm{ES}=$ Large; $\mathrm{p}=0.026)$. Over weeks 31 to 70 (39-weeks), again trivial to large ES and $-7.4 \%$ to $5.0 \%$, improvement was noted for all performance variables, with significance performance enhancement in upper body strength - bench pull $(5.0 \%$; ES = Large; $\mathrm{p}=0.013)$ and PDT-Effort $(-7.4 \% ; \mathrm{ES}=$ Large; $\mathrm{p}=0.048)$, (Table 1).

\section{Discussion}

Results of this study suggest that over 70-weeks of training, even with increases in body weight and skinfolds, NZASA performance enhanced across all nine variables, with significant improvement in four variables. Performance improvements were also recorded over weeks 31 - 70 (39-weeks), with significance being achieved in two variables, but with simultaneous decrease in skinfold and increase in body weight measurements.

The increase in body weight experienced by the NZASA has been previously reported for professional Rugby League (RL) (Till et al. 2014) and professional 
Australianmale RU players (Appleby et al. 2012). Till et al. (2014) and Appleby et al. (2012) reported, on developing athletes reaching their adult height, their body weight continues to increase due to prolonged resistance training and adequate nutrition. The NZASA body weight increases (3.2\%, weeks $1-70$ and $1.6 \%$, weeks 31 - 70) are also consistent with published data from similar age RU athletes; South African U20 RU (SARU) reported a 13\% increase in body weight over 11-years (Lombard et al. 2015) and another study using National Team ranked $11^{\text {th }}-15^{\text {th }}$ by the IRB / WR detailed increases of $1.5 \%$ over 1 year and $4.8 \%$ over 2-years (Barr et al. 2014). The increase in NZASA skinfold data over weeks 1 - 70 (weeks-39) were also comparable to published data from the English Academy RU (EARU) athletes (Darrall-Jones et al. 2015). There has been a suggestion that higher skinfold level may offer some protection during collisions (Bell 1973), however, concern has been raised regarding excessive body fat as being "dead weight" and hindering player's work rate and performance, (Duthie et al. 2003); the decrease in skin folds, after the initial increase between weeks 1 - 31, concur with published literature (Till et al. 2014; Appleby et al. 2012).

The NZASA lower body power results continued to improve over both time periods, with significant increase over weeks 1 - 70, and all NZASA data were superior when compared to available data from the EARU (Darrall-Jones et al. 2015). Published data have stated that variation in strength and power between athletes in different levels of competition are likely caused by maturation and body mass which can result to the ability to generate high levels of force and power and the higher lower body power assists with generation of greater leg drive (Argus et al. 2012) and the greater leg drive aids to counter the forward progression of the opposing player during tackling (Vaz et al. 2015). However, the higher lower body power/leg drive generation, compared to EARU data (Darrall-Jones et al. 2015), contributed to only small improvement in acceleration $(5 \mathrm{~m})$ and speed, $10 \mathrm{~m}$ and $40 \mathrm{~m} ; 3.8 \%, 0.4 \%$, and $1.2 \%$, over weeks $1-70$ and $3.1 \%, 0.3 \%$ and $1.3 \%$ over weeks $31-70$, respectively. Since sprinting requires high force production (Mero et al. 1992), NZASA data are inconsistent with published literature which have presented a strong correlation between VJ, acceleration and sprint speeds (power to weight ratio) over various distances (Cronin and Hansen 2005). As such, although NZASA data is superior to published data in the $\mathrm{VJ}$, acceleration and speed variables compared to EARU (Darrall-Jones et al. 2015) and similar to speed data from the SARU (Lombard et al. 2015), for the NZASA to increase their acceleration and speed, they must develop even greater power output to overcome the increases in body weight and/ or skinfolds measurements.

The NZASA achieved superior upper body strength 1RM bench-press results, over weeks 1 - 70 and weeks 31 - 70, compared to the EARU (DarrallJones et al. 2015) and NZ Academy RU U21 (Argus et al. 2012), but inferior to the SARU data collected over 13-years (Lombard et al. 2015). The NZASA upper body strength 1RM bench-pull data is comparable to the available EARU results (Darrall-Jones et al. 2015). The NZASA bench-press strength percent change over both durations is also consistent with previous published data from 
different football codes, the English RL Super League Academy U20 (Till et al. 2014) and North American collegiate football players (Hoffman and Kang 2003). However, Argus et al. (2012) using data from NZ Academy U21 RU athletes stated. "... by the time athletes are training in an academy system and have a training age of only 1.5 years, approximately $81 \%$ of strength and $71 \%$ of power have already been developed. Therefore, the majority of physical development appears to be attained throughout the first 1-2 years of training within a structured environment." However, Lombard et al., 2015 reported a $51 \%$ upper body strength (bench-press) increase in the SARU U20 players (participating for a minimum of 3-years in respective U20 program) over 13years. As such, the $81 \%$ strength gains reported by Argus et al. 2012 maybe a result of a higher total training age between 2.2 to 3.8, mean 3-years. Nevertheless, the strength gains recorded by the respective athletes could have been the cumulative effect of improved professionalism of developing rugby players, increased emphasis on physical enhancement strategies and decreased injury risk/rates, allowing for increased resistance training capacity/volumes (Smart and Gill 2013), which, led to adaptations in neuromuscular physiology, specifically, increased synchronization of motor units, and concurrent decreased antagonist muscle firing, as well as decreased inhibitory feedback mechanism (Argus et al. 2012; Costill et al. 1968). Also, in following Lombard et al. (2015) and Argus et al. (2015) data, the improvements in strength could also be attributed to utilizing an actively supervised training program prior to commencing a RU Academy program may allow for greater anatomical and/or physiological adaptation(s) permitting for superior physical and performance gains.

Published literature has suggested that a well-developed anaerobic metabolic system is essential for competing in elite RU competition as a result of higher playing intensity required since the inauguration of the professional RU competition (Duthie et al. 2005). However, it has also been suggested there is a lack of anaerobic data available on developing and elite RU players (Duthie et al. 2003).

Over both training durations, weeks $1-70$ and weeks $31-70$, mean performance over the respective 10 repetitions of $40 \mathrm{~m}$ (PDT-mean), improved by $1.1 \%$. This improvement coincided with a decrease in fatigue level $(7.2 \%$ over weeks $1-70$ and $3.7 \%$ over weeks 31 - 70) with significantly less effort required (PDT-Effort decreased by $6.8 \%$ over weeks $1-70$ and $7.4 \%$ over weeks 31 - 70). These data suggest, the NZASA had increased their anaerobic system efficiency due to an improvement in the anaerobic threshold as higher muscle $\mathrm{pH}$ level were maintained due to higher involvement of the aerobic system, leading to decrease in phosphocreatine activation and ATP utilisation from anaerobic glycolysis (Spencer et al. 2005; MacDougall et al. 1998).

The results from weeks 31 - 70 suggest, (1) performance enhancement is possible after the initial introduction to an actively supervised training program and after a limited duration of non-actively-supervised training period, (2) body weight may continue to increase, (3) skin-fold measurement increase mostly over the initial 31-weeks and then should start to decrease with continued adequate training, and (4) that adaptations to the anaerobic systems may not be 
evident during early training period (weeks 1 to 31 ) as a longer duration is required to achieve performance enhancement. The data from weeks 1 - 70 support Lombard et al. (2015) and Barr et al. (2014) findings which demonstrated strength and power gains occur at a slower rate and over a longer duration than predominantly over the first two years, while, acceleration, and speed variables follow a similar trend.

\section{Conclusions}

The present study demonstrated that over the 70-weeks of active-, non-active, and again active-training supervision, increases in body weight and skin-fold measurements still lead to performance enhancement in acceleration, speed, lower body power, upper body strength, and anaerobic capacity, with significant gains in the latter three performance variables. Following the same training schedule over the latter 39-weeks (weeks 31 to 70), also led to an increase in body weight, but skin-fold measurements decreased; suggesting skin-folds measurements increase primarily over the early training duration and performance improved in all variables with significant improvements in upper-body strength - bench pull and PDT-Effort.

In addition to the above findings, several other findings were determined for Academy/developing student-athletes. First, power and strength gains seem to occur at a slower rate and over a longer duration; contrary to some of the published literature. Second, commencing appropriate actively supervised strength and conditioning training at an earlier age during high school may allow greater anatomical and/or physiological adaptations allowing for superior physical and performance gains. Third, while active monitoring/supervision during training is the 'gold standard', but may not be always possible for various reasons, using online, non-video, training monitoring can still lead to performance enhancement, at the very least, sustain performance levels. Lastly, future research should consider longitudinal versus cross-over study design since there is a lack of long term data available on developing RU athletes.

\section{References}

Appleby B, Newton RU, Cormie P (2012) Changes in strength over a 20 year period in professional rugby union players. Journal of Strength and Conditioning Research 26: $2538-2546$.

Argus CK, Gill N, Keogh JWL (2012) Characterization of the differences in strength and power between different levels of competition in rugby union athletes. Journal of Strength and Conditioning Research 26: 2698-2704.

Baker D, Newton RU (2008) Comparison of lowerbody strength, power, acceleration, speed, agility, and sprint momentum to describe and compare playing rank among professional rugby league players. Journal of Strength and Conditioning Research22: $153-158$. 
Barr MJ, Sheppard JM, Gabbett TJ, et al. (2014) Long-term training-induced changes in sprinting speed and sprint momentum in elite rugby union players. Journal of Strength and Conditioning Research 28: 2724-2731.

Bell W (1973) Distribution of skinfolds and differences in body proportions in young adult rugby players. Journal of Sports Medicine and Physical Fitness 13: 69-73.

Cahill N, Lamb K, Worsfold P, et al. (2013) The movement characteristics of English Premiership Rugby Union players. Journal of Sports Sciences 31: 229-237.

Cohen J (1988) Statistical Power Analysis for the Behavioral Sciences, Hillsdale, NJ: Lawrence Erlbaum Assoc.

Costill DL, Miller SJ, Myers WC, et al. (1968) Relationship among selected tests of explosive leg strength and power. Research Quarterly. American Association for Health, Physical Education and Recreation 39: 785-787.

Coutts A, Reaburn P, Piva TJ, et al. (2007) Changes in selected biochemical, muscular strength, power, and endurance measures during deliberate overreaching and tapering in rugby league players. International Journal of Sports Medicine 28: 116-124.

Cronin JB, Hansen KT (2005) Strength and power predictors of sports speed. Journal of Strength and Conditioning Research 19: 349-357.

Darrall-Jones JD, Jones B, Till K (2015) Anthropometric and physical profiles of English Academy Rugby Union Players Journal of Strength and Conditioning Research 29: 2086-2096.

Duthie G, Pyne D and Hooper S (2003) Applied physiology and game analysis of rugby union. Sports Medicine 33: 973-991.

Duthie G, Pyne D, Hooper S (2005) Time motion analysis of 2001 and 2002 super 12 rugby. Journal of Sports Sciences 23: 523-530.

Glaister M, Howatson G, Lockey RS, et al. (2007) Familiarization and reliability of multiple sprint running performance indices. Journal of Strength and Conditioning Research 21: 857-859.

Hawes MR, Martin AD (2001) Human body composition. In: Reilly REaT (ed) Kinanthropometry and exercise physiology laboratory manual: Tests, procedures and data. Anthropometry. 2nd ed. London: Routledge, 7-43.

Hendrick A, Anderson JC (1996) The vertical jump: A review of the literature and team case study. Strength \& Conditioning Journal 18: 7-12.

Hoffman JR, Kang J (2003) Strength changes during an in-season resistance-training program for football. Journal of Strength and Conditioning Research 17: 109-114.

Lawton TW, Cronin JB, McGuigan MR (2011) Strength testing and training of rowers: A review. Sports Medicine 41: 413-422.

Lombard WP, Durandt JJ, Masimla H, et al. (2015) Changes in body size and physical characteristics of South African under-20 Rugby Union players over a 13-year period. Journal of Strength and Conditioning Research 29: 980-988.

MacDougall JD, Hicks AL, MacDonald JR, et al. (1998) Muscle performance and enzymatic adaptations to sprint interval training. Journal of Applied Physiology 84: 2138-2142.

McCurdy K, Langford G, Jenkerson D, et al. (2008) The validity and reliability of the $1 \mathrm{RM}$ bench press using chain-loaded resistance. Journal of Strength and Conditioning Research 22: 678-683.

Mero A, Komi PV, Gregor R (1992) Biomechanics of sprint running. Sports Medicine 6.

Moir G, Button C, Glasister M, et al. (2004) Influence of familiarization on the reliability of vertical jump and acceleration sprinting performance in physically active men. Journal of Strength and Conditioning Research 18: 276-280. 
Parker Z (2013) Factors Associated with Success in South African Rugby Union. Faculty of Health Sciences. Cape Town, South Africa: University of Cape Town. $1-63$.

Quarrie KL, Handcock P, Waller AE (1995) The New Zealand rugby injury and performance project. III. Anthropometric and physical performance characteristics of players. British Journal of Sports Medicine 29: 263-270.

Seo DI, Kim E, Fahs CA, et al. (2012) Reliability of the one-repetition maximum test based on muscle group and gender. Journal of Sports Science and Medicine 11: 221-225.

Smart DJ, Gill ND (2013) Effects of an off-season conditioning program on the physical characteristics of adolescent rugby union players. Journal of Strength and Conditioning Research 27: 708-713.

Smart DJ, Hopkins GW, Gill DN (2013) Difference and changes in the physical characteristics of professional and amateur rugby union players. Journal of Strength and Conditioning Research 27: 3033-3044.

Spencer M, Bishop D, Dawson B, et al. (2005) Physiological and metabolic responses of repeated-sprint activities: specific to field-based team sports. Sports Medicine 35: 1025-1044.

Till K, Tester E, Jones B, et al. (2014) Anthropometric and physical characteristics of english academy rugby league players. Journal of Strength and Conditioning Research 28: 319-327.

Tønnessen E, Shalfawi SA, Haugen T, et al. (2011) The effect of 40-m repeated sprint training on maximum sprinting speed, repeated sprint speed endurance, vertical jump, and aerobic capacity in young elite male soccer players. Journal of Strength and Conditioning Research 25: 2364-2370.

Vaz L, Vasilica I, Carreras D, et al. (2015) Physical fitness profiles of elite under-19 rugby union players. Journal of Sports Medicine and Physical Fitness. 
